\title{
NUMERACY STUDENTS' PERSPECTIVES ON A NEW DIGITAL LEARNING TOOL AT A SOUTH AFRICAN UNIVERSITY
}

\author{
D. H. Delport
}

Department of Mathematics and Physical Sciences

Central University of Technology, Free State

Bloemfontein, South Africa

e-mail: ddelport@cut.ac.za

\section{ABSTRACT}

Students thrive in learning environments where they are able to remain engaged, interested and motivated. A new digital learning tool, MindTap Math Foundations, claims to transform learning by bringing elements from the interactive, gamified world so that students stay engaged, persist through challenges, feel more supported and connected with instructors, other students and their own learning experience. A South African university was the first higher education institution in South Africa to make use of this personalised learning system. A survey was employed to assess the effectiveness of MindTap Math Foundations as a digital learning tool. The focus of the article is on the analysis of the open-ended questions in the survey. The findings of this research support the claims Cengage make regarding the platform's benefits. Participants' responses revealed that the new digital learning tool is generally perceived as positive and beneficial for learning numeracy. Students' feedback also provided ideas and proposals for potential enhancement. Through students' experiences shared it was possible to pinpoint the strengths and challenges regarding aspects needing consideration and improvement.

Key words: MindTap Math Foundations, digital learning tool, Numeracy students, South African university

\section{INTRODUCTION}

"That is the way to learn the most ... When you are doing something with such enjoyment that you don't notice that the time passes." (Albert Einstein)

Einstein's positive perspective on learning illustrates the importance of fostering learning environments in which students stay engaged, interested and motivated. Jaffer, $\mathrm{Ng}$ 'ambi and Czerniewicz $(2007,131)$ emphasise that we should "provide additional strategies that can be used to address the serious environmental and educational challenges faced by educators and students in higher education". Pierre Aurel (2018) purports that in an era driven and dominated by technology, South Africa cannot succeed by clinging to an obsolete and broken educational system. We should adapt and reconsider how we share knowledge, teach and learn in the digital 
era. Given South Africa's scale, adopting a digital mindset and working with strategic partners to address the content of educational challenges may improve education. However, as far as technology integration into the classroom situation is concerned, the instructor is still mainly responsible for facilitating this educational innovation (Chen, Looi and Chen 2009; Vanderlinde and Van Braak 2011).

Digital technology, as a potential means of transforming education, has been a major development and research theme since the 1950s (Saljo 2010, 54). Digital technologies, instead of non-digital technologies, are applied in support of learning and teaching, whilst the ubiquity and convenience of the internet makes it suitable for purposes of applying digital teaching materials, and as such the internet is replacing traditional teaching applications (Lin, Chen and Liu 2017; Hughes 2005; Warschauer 2007; Windschitl 1998). Research has demonstrated that the use of digital technology has improved teaching and learning (Waghid and Waghid 2016; Higgins, Xiao and Katsipataki 2012; Chaka and Govender 2017; Mouyabi 2011). Wankle $(2011,7)$ states that the use of digital technology could act as a catalyst for cultivating interaction, sharing and excitement in students.

Along with advancements in digital technology, hardware and software developers are constantly promoting new technological tools. In March 2016, Cengage Learning (2018) announced MindTap Math Foundations, a digital learning solution that was designed with students, for students. Cengage Learning $(2018,1)$ claims that "MindTap Math Foundations break down the barriers to course completion by introducing aspects from the interactive gamified world to transform learning so that learners remain engaged, persist through challenges, feel more supported and connected to teachers, other students, as well as their own learning”. For Prensky $(2003,1)$, “it is the very attitude we would all like our learners to have: interested, competitive, cooperative, results-oriented, actively seeking information and solutions".

A South African university was the first higher education institution in South Africa to pilot this new digital learning solution. The aim of the study was to facilitate this new digital learning solution for Numeracy students at the university, to critically evaluate its effectiveness, and report on students' views and opinions about MindTap Math Foundations during the first semester of 2018. The findings of this pilot study would then be used to modify the planned programme, if needed. Through students' experiences, the study aimed to identify the strengths and challenges with regard to the digital learning tool. The findings of this research can provide other universities in South Africa with some broad guidelines with regards to the implementation of MindTap Math Foundations as a digital learning tool. As large classes affect educators globally, an international audience may also benefit from the findings of the research. 
To shed light on the implementation and perceived usability of MindTap Math Foundations, the following research questions were set:

Q1: How was MindTap Math Foundations implemented and perceived?

Q2: What are students' views towards this digital learning tool?

\section{LITERATURE REVIEW}

In the changing higher education landscape where there is a need to include new technologies, it is vital to know the scope of such technologies as well as the influence of learning in the classroom. In this review three aspects are focused on, namely the digital technologies, the effects of learning and an application tool.

\section{Digital technologies}

Over the past 20 years, the impact of digital technology on learning has changed. Web access, the nature of the internet, the learning context and the advancement of anticipated technological competencies for students, administrators and teachers have been transformed (Greenhow, Robelia and Hughes 2009, 246). Research evidence with regard to the effect of digital technologies on learning constantly identifies favourable outcomes (Higgins et al. 2012; Lin et al. 2017; Chaka and Govender 2017; Mouyabi 2011). Digital tools not only elevate instruction and reinforce student engagement, but also solve many contemporary instructional challenges. Digital learning, unlike traditional learning, enables learners not to be limited to time and space, which enables them to choose where and when they would like to make use of online learning tools (Jude, Kajura and Birevu 2014; Tshibalo 2007). Apart from investigations into the effect of digital technologies on learning in general, a large body of literature has investigated digital technologies with regard to numeracy as a teaching and learning discipline. However, the focus is mainly on the role of digital technologies, students and teachers in technology-enriched classrooms (Goos, Geiger and Dole 2010; Drijvers and Weigand 2010; Spencer 2013; Lerman and Zevenberger 2006).

Gamification is one such a popular tool currently used in education. In coordination with technological developments, digital learning games are to an increasing extent being used as a reference medium in the education arena and form an innovative instructional paradigm incorporated into education. Although utilising games for purposes of teaching educational content and their compatibility with deep learning has been questioned in the past (Graesser et al. 2009; Vander Ark 2011), emerging research emphasises the real benefits of digital games in terms of motivation, learning and engagement, when compared to traditional educational methods (Connolly et al. 2012; Prensky 2001; Villagrasa et al. 2014). 
According to Kapp $(2012,11)$, learning gamification can be defined as "an educational approach to motivate students to learn by performing video game design and by using game elements within learning environments". A critical look into literature has identified some benefits of gamified learning.

\section{Learning effects}

Benefits of gamified learning include an increase in knowledge retention, reflective thinking and outcomes such as self-determination, motivation and engagement.

Increased knowledge retention occurs when learners play games. These games emerge from personal learning experiences, which in regular instructional environments are less accessible (Vos, Van der Meijden and Denessen 2011, 128). Gamification provides students with the ability to learn when they want to and are ready to learn, instead of when the teacher is ready (Kapp 2012). Research has shown that this approach improves the retention of knowledge while engaging students in an immerse learning environment (Brull and Finlayson 2016; Randall et al. 1992).

Reflective thinking can take place when learners play games. They reflect on their actions and come to conclusions, modify and re-test their hypotheses (Gee 2003). This so-called "trial-and-error" approach was believed to support the development of logical thinking, problem-solving and critical thinking skills (McFarlane, Sparrowhawk and Head 2002; Gee 2003; Kirriemuir and McFarlane 2004; Wideman et al. 2007). Research has shown how critical thinking helps learners evaluate other people's, as well as their own arguments, resolve conflicts, and find solutions to complex problems (Allegretti and Frederick 1995). As learners continuously participate, knowledge, learning and development improve. Gamification therefore enables learners through doing, which results in an improvement in processes and outcomes (Schute and Ventura 2013). Gee (2003) emphasises that these attributes of game playing could aid in the construction of knowledge, and eventually result in deep learning.

Outcomes such as self-determination, motivation and engagement often result from the use of technologies in learning. Many gaming experts argue that gamification contributes positively to the learning environment, based on the principles of the theory of self-determination, which is often linked to motivation, and include competence, independence and relatedness (Werbach and Hunter 2012; Ryan and Deci 2000). Extrinsic motivators such as doing well and motivating oneself simply to get to the next level when playing video games seem hardly inspirational as an educational goal for tertiary students. However, students who are intrinsically motivated will end up feeling challenged, enriched, energetic and eventually fulfilled (Ryan and Deci 2000; Martens, Gulikers and Bastiaens 2004). According to Kapp 
(2012), gamification aims to meet learners' intrinsic needs by offering them instant feedback, providing control over the learning material, and increasing their curiosity. A study by Liu et al. (2011) revealed a positive link between intrinsic motivation and learning results obtained in a digital learning game. As far as motivation and engagement are concerned, the advantages of learning via digital games are positively linked to its entertainment aspect, as it increases inquisitiveness in learners by demonstrating learning practices in significant ways (Kirriemuir and McFarlane 2004; Annetta et al. 2009). Although little research is available with regards to gamification in Numeracy as a learning and teaching discipline, a few studies demonstrated the effectiveness of gamification in math education, by increasing student motivation and interest (Sakai and Shiota 2016; Kebritchi, Hirumi and Bai 2010).

In order to bring about deeper learning, it is necessary to determine which experiences contribute to learning. According to Vander Ark $(2011,8)$, deeper learning involves changes in content, instruction and assessment for purposes of encouraging greater engagement among students, by making use of lessons and learning material that stimulate investigation, communication, collaboration and critical thinking. Educators emphasise that learners need to develop such skills whilst learning, as these skills enable them to take part in self-regulatory and purposeful judgment (Behar 2011, 25). It can therefore be asserted that games focusing on educational objectives and subject matter can assist in making learning easier, more enjoyable, learning-centered, and more interesting, and therefore more effective (Kafai 2001; Malone 1980; Prensky 2001). It is therefore important to attempt to merge learning content and the use of games in the learning process (Prensky 2003).

\section{Application tool}

In March 2016, Cengage Learning (2018) announced MindTap Math Foundations, a product developed in collaboration with students, for students. According to Cengage (2018), MindTap Developmental Mathematics is a highly customised learning system that focuses on four key student development areas: engagement, persistence, retention and critical thinking. Apart from game activities, interactive video lessons and multiple features engage students by going beyond checking key concepts for understanding and draw students into the content to build student attributes such as critical thinking and problem-solving that are deemed critical by universities.

Literature suggest that gamification has positive effects on students' motivation, engagement and interests. However, deep learning involves modifications in content, instruction and assessment to promote greater student engagement, and lessons that encourage critical thinking, communication, collaboration and investigation. Cengage's Learning (2018) 
claims regarding MindTap Math support the notion of deep learning by concentrating on four key student development areas, which are: Engagement, Persistence, Retention and Critical Thinking. As opposed to other digital learning tools, this digital platform seems to have multiple features that makes learning more manageable.

\section{METHODOLOGY}

\section{Background to the study}

During 2017, the researcher had several meetings with Cengage Learning (2018) to plan the implementation of MindTap Math Foundations at the university. The syllabus for Numeracy was also discussed and planned accordingly. Cengage built this content into the MindTap Math Foundation programme, and omitted units that were not part of the Numeracy syllabus. Cengage technicians and administrators also met with the student digital platform administrators (the student learning portal for this university) towards the end of 2017 to discuss possible ways for students to access the MindTap Math Foundations learning tool online. It was then decided to integrate this new digital learning solution with the student digital platform, and to merge the Numeracy content with all their other subjects they automatically had access to as registered students. Once students were registered for Numeracy, they automatically had access to the Cengage MindTap Math Foundations software on the student digital platform. When opening the link provided, students had access to all the instructional material for Numeracy.

Four part-time lecturers were appointed to teach Numeracy at the university. Each lecturer had about 280 students, with two lectures with students per week. Each lecture consisted of two 40-minute periods. The lecturers adhered to the time schedule and covered a new topic/unit every second week. Numeracy comprised nine learning units. After completion of each unit, the coordinator set an online test and made an announcement on the student digital platform to make students aware that a new test is available for completion online. Students had access to several venues on campus with computers, as well as to free $\mathrm{WiFi}$. The researcher gave students two weeks to complete each test. A total of nine tests were conducted during the first semester of 2018. Each test was designed to be objective, and answers to questions were marked by the programme as either correct or incorrect.

\section{Research design}

As part of a larger study, this article reports on the qualitative data obtained by means of open-ended questions as part of the study to evaluate how successfully the MindTap Math Foundations tool was implemented. The focus of this article is on the research sub-question: 
What are students' views and perceptions toward the new digital learning tool? A qualitative design was used to collect in-depth information on students' experiences of the new digital learning tool. Windschitl (1998) encourages researchers to use qualitative research methods to explore, document and describe web-based learning and teaching developments.

\section{Population}

A group of first-year students at the university was selected for this research project. All 1100 registered first-year students who enrolled for Numeracy at the university were invited to participate in the study. Thus, a convenience sampling technique was used for this study, as the participants were already available and formed part of the Numeracy classes (McMillan and Schumacher 2006, 125).

\section{Data collection method}

The researcher compiled a questionnaire by means of QuestionPro survey software to gauge students' perceptions of and feelings towards the MindTap Math Foundations digital learning tool. This data collection measure was employed at the end of the semester course, and the survey was administered online. The link to the survey was uploaded on students' Numeracy content on the student digital platform. The researcher informed Numeracy students about the purpose of the survey, and that their perceptions and feedback would be valuable regarding the evaluation of the new digital learning tool. The questionnaire included only three open-ended questions. The researcher deemed it necessary to include open-ended questions to encourage complete and meaningful answers by obtaining the students' own experience of, and feelings about the new digital learning tool. The questions were short and clear, and the researcher used simple language to prevent response bias among students. An expert in the field of research reviewed the questions. The questions were:

1. Which factors contributed to your success in Numeracy?

2. What factors contributed to your struggle in Numeracy?

3. What do you think lecturers should do to make your experience with Numeracy better?

According to Foddy $(1993,127)$ "open-ended questions allow the respondent to express an opinion without being influenced by the researcher". This free-form written responses reveal how participants think, and much can be learned from their own words and from reading their thoughts. This also allowed the researcher to build a better picture of how to improve, if necessary, the use of the new digital online learning tool. 


\section{Data analysis}

To answer the first researcher question and investigate the perceived usability of the new digital learning tool, the researcher kept a journal of problems that were identified when the digital learning tool was first implemented. For purposes of answering the second research question, the researcher used thematic analysis to analyse students' responses with regard to the open-ended questions. According to Braun and Clarke $(2012,57)$, "thematic analysis is a method for systematically identifying, organising, and offering insights into patterns of meaning (themes) across a data set". The researcher used Braun and Clarke's six-phase guide as a framework to perform the analysis (Braun and Clarke 2006). The researcher first read through all the transcripts. Data were then organised in a systematic way and coded to reduce the data into small meaningful chunks. The researcher organised the codes into broader themes that seemed to say something about the research questions. Themes were then reviewed and defined. In the final step, the results are reported. To facilitate anonymity, S1 was used for student 1 . As verbatim information is provided, it may contain grammatical and spelling errors.

\section{RESULTS AND DISCUSSION}

The findings related to factors contributing to the success and struggles of participants, as well as their suggestions for improvement, are discussed.

\section{Factors contributing to success in Numeracy}

Four broad themes emerged from the responses of students including activities, thinking skills, math background and self-regulated learning.

Many students felt that the activities on the MindTap Math Foundations platform in particular were quite helpful. A recurrent theme students' mentioned was how the games helped them with learning Numeracy. Responses like "games showing you how to tackle problems" (S13) and "the build-up games really helped me improved and understand what the test was all about and also the step-by-step option came in handy" (S158). Apart from mentioning the games on the digital learning platform, a few students also stated that the video lessons and whiteboard came in handy: "The fact that there is a recording of an instructor who helped through the difficult questions that I faced. And the white board came in very handy most of the time when it became difficult to solve some equations" (S39), "the interactive videos give you a clear understanding on how to handle the content in the test" (S54). The whiteboard reinforced content and skills specific to learning objectives, and encouraged students to make use of critical thinking skills. It is clear from the comments above that these students enjoyed studying, and reported a deeper understanding of numeracy. As seen from students' responses, 
intrinsic motivation appeared to have improved with the introduction of gamification on the MindTap Math Foundations platform, as it prompted students to participate in curiosity-driven exploration, effort, and participation, and not to focus only on explicit reward, as suggested by Burgiollo (2010).

A variety of perspectives were expressed with regard to thinking skills. One student said: "I learned new skills throughout the tests" (S57), "calculating without using a calculator determines/measures how fast I am to answer questions especially numbers" (S64), "more knowledge regarding the content" (S19), "working with numbers without using a calculator" (S79), "being able to solve problems even counting skills have improved rapidly" (S21). Students' comprehension of important math skills were reinforced. Although these comments focus on students individually, other students mentioned the social aspect of learning: "my own understanding and help from the class" (S42) and "Getting help from other students" (S31). When students learn from each other, they hear of different interpretations they did not think of themselves. This shared knowledge makes it possible to generally help each other and to verify their own insecure interpretations of the content procedure" (Biggs and Tang 2007, 126). The reflective element of learning is therefore sharpened, as learners identify with each other's learning in a manner different from how they would when a top-down, teacher-directed learning method is followed" (Biggs and Tang 2007, 140).

A recurrent theme in students' responses were their prior knowledge and math background: "I did mathematical literacy at school, so it was easy for me to do the tests online" (S115), "the fact that I did mathematics at school helped me a lot on my skills than attending lectures" (S60). New learning is built on previous understanding. When we learn new concepts, we bring forward the knowledge that we have already incorporated into our understanding of the topic. Previous research validates the significant contribution of prior knowledge to the academic success of students (Marzano, Gaddy and Dean 2000; Smith, Lee, and Newmann 2001).

Students also mentioned aspects of self-regulated learning. There was a sense of persistence or perseverance among students with regard to the new digital learning tool. One student stated: "using the knowledge that I have for maths and practising whenever I get the chance" (S02).

\section{Factors contributing to challenges in Numeracy}

A number of issues such as mathematics background, students blaming themselves or their lecturers, and limited computer resources were identified with regard to students' struggles in Numeracy. Many students indicated that their previous mathematics background had an 
influence on their Numeracy skills. Some responses were: "Some of the things I didn't know because I didn't had pure maths in high school" (S28), "forgetting basic skills" (S54). This confirms the contention of Ambrose et al. (2010) that prior knowledge determines future learning and performance. Students use what they know as the foundation and the building blocks for new knowledge. However, if students have insufficient prior knowledge about numbers, these may act as an impediment or a stumbling block, which can limit students' learning as well as performance.

Although some students indicated that their previous Mathematics background was a factor that contributed toward their struggle in numeracy, a few students blamed themselves. For example, in their accounts a few students mentioned: "not going through the student digital platform each and every day" (S60), "not practicing" (S78 and student 119), "laziness" (student 117) and "ignorance" (S103). It seems as if these learners want to finish the task with minimal effort. Learning has become a drag for these learners, and they do not find any pleasure in doing the task.

Some students blamed their lecturer or the online learning tool for their struggle in numeracy. "The tests take long hours to finish" (S38), and "the games consume more time and make a student tired before even starting with the test" (student 100). A few students blamed their lecturer for their poor performance, for example: "lecturer switching" (S11) and "failing to understand my lecturer during class as he was moving too fast" (S159). These factors echo the findings of Gow, Kember and Sivan (1992), who identified three categories of reasons provided for students failing to achieve course objectives, namely blaming the lecturer, blaming the student, and blaming the system.

A recurrent theme that emerged from students' responses were the limited access they had to computers or being computer illiterate. Responses to support this finding include the following: "no permanent access to online activities" (S10), "not having the physical resources to do it anywhere" (S58), "shortage of computers in lab" (S122). This problem echoes the findings of Plomp and Pelgrum (1993) and Alexander (2005) with regard to limited access to computers.

Some students could not fault the new digital learning tool and responded positively with remarks such as: "None ... even if most complain about the online structure not being the same as writing from a physical question paper, I find it the same. I can read the question on the computer and work it out on paper and find the answer and type it on the computer. Saying the internet has confusions is just a stubborn mindset of not wanting to try something new" (S80). This specific comment that emanated from the responses was interesting in a few ways. It summed up a few aspects at once. It seems like this specific student also applied critical thinking 
skills when answering this question.

\section{Guidelines for lecturers to make students' experience with Numeracy better}

Students mentioned what they think lecturers can do to improve their teaching style during lecturing sessions. This finding is supported by responses such as: "Show more examples for those students who do not understand" (S48), "offer tutorials" (S63), "engage students in group activities to assist struggling students" (S51), and "help us to form study groups". Collaborative learning is frequently demonstrated when student groups work together to find understanding, meaning or solutions. Research has shown that peer learning is one technique of promoting meaningful learning, involving learners to teach and to learn from one another (Herrmann 2013). Collaborative learning approaches is therefore a powerful way to reinforce course concepts and promote understanding among students, as they capitalise on one another's resources and skills.

A variety of perspectives were expressed with regard to the MindTap Math Foundations online system, and some students felt that lecturers can improve on the following: "provide slides to help people who do not have access to a computer" (S7). These responses suggest that students experienced difficulties with the digital tool, whether it was technical problems, or not having permanent access to a computer. This echoes the findings of Pelgrum (2001), who identified lack of computers as an obstacle with regard to ICT in education.

Some respondents indicated that the lecturers had done enough and that nothing should be changed. This is evident from the following responses by students: "Nothing because the numeracy online tests and activities cover everything" (S6), "online activities and tests are better because students understand more when they see everything unfold and demonstrated step by step" (S118) and "I got what I needed but I felt classes were really unnecessary" (S10).

Responses revealed individual differences with regard to the new digital learning tool. Some students practiced online every day, while others admitted that they are ignorant and lazy, and that they waited until the last minute to complete their online tests.

Overall students viewed MindTap Math Foundations positively. Students highlighted the games and videos as features that made MindTap Math a fun and engaging learning environment conducive to improve critical thinking skills in Numeracy. A primary reason for the students' high motivation to use MindTap Math seems to be the platform's interactive, game-oriented, web-based design. From the responses it seems that these characteristics provided opportunities for individual learning as well as flexible use of content material in different contexts. Students also pointed out that the web-based format enabled them to work individually and at their own pace, supporting more detailed comprehension of certain aspects of Numeracy. On the other 
hand, some students still prefer traditional ways of teaching and did not like the online learningtool and assessments. Some reasons for students' negativity toward MindTap Math included that they are computer illiterate, do not take their studies seriously, are not selfdisciplined, do not read announcements that were made on the university's digital platform, and that they wait until the last minute to complete the online tests. Students' comments seem to correlate with the learning outcomes listed in Figure 1. The multiple features of MindTap Math are summarised in Figure 1, as well as what Cengage claims it can do. The learning outcome is summarised in the last column.

\begin{tabular}{|c|c|c|}
\hline $\begin{array}{l}\text { MindTap Math } \\
\text { Features }\end{array}$ & What it claims to do & Learning outcome \\
\hline \multirow{3}{*}{$\begin{array}{l}\text { Short check-in } \\
\text { assessment \& } \\
\text { assignments }\end{array}$} & Check prior knowledge & Reflection \\
\hline & Tracking mastery on skills & Critical thinking skills \\
\hline & & Motivation \\
\hline \multirow{2}{*}{$\begin{array}{l}\text { Practising with 15- } \\
\text { minute learning } \\
\text { "bursts" }\end{array}$} & $\begin{array}{l}\text { Provide quick, targeted practice based on } \\
\text { previous work }\end{array}$ & Reflection \\
\hline & $\begin{array}{l}\text { Reinforce comprehension of important maths } \\
\text { skills }\end{array}$ & Critical thinking skills \\
\hline \multirow{2}{*}{$\begin{array}{l}\text { Video Tutorials \& } \\
\text { Concept Builders }\end{array}$} & Encourage understanding & Motivation \\
\hline & Motivate students to continue & Persistence / Perseverance \\
\hline $\begin{array}{l}\text { Games-based } \\
\text { learning activities }\end{array}$ & Building confidence & $\begin{array}{l}\text { Keeps students interested and } \\
\text { motivated }\end{array}$ \\
\hline Dashboard & $\begin{array}{l}\text { A visual progress tracker that allows students } \\
\text { to monitor progress }\end{array}$ & $\begin{array}{l}\text { Students reflect on / monitor their own } \\
\text { progress }\end{array}$ \\
\hline \multirow[t]{4}{*}{$\begin{array}{l}\text { Chat, announcements } \\
\& \text { Whiteboard }\end{array}$} & $\begin{array}{l}\text { Support collaboration between a student and } \\
\text { an instructor and/or peers }\end{array}$ & $\begin{array}{l}\text { Keeping students engaged and } \\
\text { interested }\end{array}$ \\
\hline & & $\begin{array}{l}\text { Allows collaboration among students / } \\
\text { peer learning / mediation }\end{array}$ \\
\hline & Reinforce students' understanding of concepts & $\begin{array}{l}\text { Reflect, evaluate and monitor own } \\
\text { understanding }\end{array}$ \\
\hline & $\begin{array}{l}\text { Reinforce content and skills specific to learning } \\
\text { objectives }\end{array}$ & Critical thinking skills \\
\hline
\end{tabular}

Figure 1: MindTap Math Features

Overall, the students' views of the new online digital learning tool support the claims made by Cengage that the platform is engaging, fun and a collaborative environment for students to learn and practise. 


\section{CONCLUSION}

A positive perspective on learning illustrates the importance of fostering learning environments in which students stay engaged, interested and motivated. Cengage introduced MindTap Math Foundations, which they report is a "first of its kind" digital learning tool which incorporates all elements of deep learning. Various learning tools exist, but it is not clear whether these tools contribute to deep learning.

This study therefore provided insights into how first-year Numeracy students experienced MindTap Math Foundations as a digital learning tool. The knowledge gained from the survey provided evidence in support of the claims Cengage make regarding the platform's benefits. Participants' responses revealed that the digital learning tool was perceived as positive and beneficial for learning numeracy. Students' responses seemed to align with the views of Cengage, which is to constitute a fun, engaging, and collaborative learning environment. This learning experience could give students a sense of success and accomplishment, assist them to remain engaged and persist through challenges, while feeling more supported and connected with teachers and other learners, as well as their own learning experience. The students' feedback also provided ideas and proposals of potential enhancement for the learning institution. Through students' experiences it was possible to identify the strengths and challenges about aspects that required consideration and improvement. Some proposed enhancements included:

- Training of students in the university's digital platform;

- Helping students who are computer illiterate;

- Providing assistance to students who do not understand some numeracy content by means of supplementary instruction classes, extra examples, and group activities; and

- Increasing the number of computers available in laboratories and the library.

An important measure that might be executed to support the implementation of MindTap Math Foundations would be to create a detailed instruction manual in the form of a booklet. This has to include screenshots of how to log onto the student digital platform, follow links, as well as examples of typical errors that might occur, and how to deal with them.

Although the study provides various contributions, there are some limitations. The study included a relatively small sample size from the population of first-year students, and therefore it is recommended that future evaluations studies include bigger sample sizes from different year groups.

The findings of this research can therefore provide other universities in South Africa or 
other developing contexts with broad guidelines regarding the implementation of MindTap Math Foundations as a digital learning tool.

\section{REFERENCES}

Alexander, R. J. 2005. Teaching through dialogue: The first year. London: London Borough of Barking and Dagenham.

Allegretti, C. L. and J. N. Frederick. 1995. A model of thinking critically about ethical issues. Teaching of Psychology 22(1): 46-48.

Ambrose, S. A., M. W. Bridges, M. DiPietro, M. C. Lovett and M. K. Norman. 2010. How learning works: Seven research-based principles for smart teaching. John Wiley \& Sons.

Annetta, L. A., J. Minogue, S. Y. Holmes and M. T. Cheng. 2009. Investigating the impact of video games on high school students' engagement and learning about genetics. Computers \& Education 53(1): 74-85.

Aurel, P. 2018. Bizcommunity. Digital the key to educational success in South Africa. http://bizcommunity.com (Accessed 21 November 2018).

Behar, L. S. 2011. Teaching critical thinking skills in higher education: A review of the literature. Journal of College Teaching and Learning 8(2): 25-42.

Biggs, J. and C. Tang. 2007. Teaching for quality learning at university Maidenhead. Berkshire, UK: McGraw-Hill Education.

Braun, V. and V. Clarke. 2006. Using thematic analysis in psychology. Qualitative Research in Psychology 3: 77-101.

Braun, V. and V. Clarke. 2012. Thematic analysis. In The handbook of research methods in psychology, ed. H. Cooper. Washington, DC: American Psychological Association.

Brull, S. and S. Finlayson. 2016. Importance of gamification in increasing learning. The Journal of Continuing Education in Nursing 47(8): 372-375.

Burgiollo, J. C. 2010. Using gaming theory and competition-based learning to stimulate student motivation and performance. Computers \& Education 55(2): 566-575.

Cengage Learning. 2018. Cengage. http://www.cengage.com/mindtap/devmathdemo.com (Accessed 5 August 2018).

Chaka, J. G. and I. Govender. 2017. Students' perceptions and readiness towards mobile learning in colleges of education: A Nigerian perspective. South African Journal of Education 37(1): 1-12.

Chen, F. H., C. K. Looi and W. Chen. 2009. Integrating technology in the classroom: A visual conceptualization of teachers' knowledge, goals and beliefs. Journal of Computer Assisted Learning 25(5): 470-488.

Connolly, T. M., E. A. Boyle, E. MacArthur, T. Hainey and J. M. Boyle. 2012. A systematic literature review of empirical evidence on computer games and serious games. Computers \& Education 59(2): 661-686.

Drijvers, P. and H. G. Weigand. 2010. The role of handheld technology in the mathematics classroom. The International Journal of Mathematics Education 42(7): 665-666.

Foddy, W. 1993. Constructing questions for interviews and questionnaires: Theory and practice in social research. Cambridge: Cambridge University Press.

Gee, J. P. 2003. What video games have to teach us about learning and literacy. Computers in Entertainment 1(1): 20-20.

Goos, M., V. Geiger and S. Dole. 2010. Auditing the numeracy demands of the middle years' curriculum. In Shaping the future of mathematics education. Proceedings of the $33^{\text {rd }}$ annual conference of the Mathematics Education Research group of Australasia, ed, L. Sparrow, B. Kissane and C. Hurst. 3-7 July 2010. Fremantle: MERGA. 
Gow, L., D. Kember and A. Sivan. 1992. Lecturers' views of their teaching practices: Implications for staff development needs. Higher Education Research and Development 11(2): 135-149.

Graesser, A., P. Chipman, F. Leeming and S. Biedenbach. 2009. Deep learning and emotion in serious games. Serious games: Mechanisms and effects, 81-100.

Greenhow, C., B. Robelia and J. E. Hughes. 2009. Learning, teaching, and scholarship in a digital age. Web 2.0 and classroom research: What path should we take now? Educational Researcher 38(4): 246-259.

Herrmann, K. J. 2013. The impact of cooperative learning on student engagement: Results from an intervention. Active learning in higher education 14(3): 175-187.

Higgins, S., Z. Xiao and M. Katsipataki. 2012. The impact of digital technology on learning: A summary for the Education Endowment Foundation. http://educationendowmentfoundation.org.uk/ uploads/pdf/The_impact_of_Digital_Technologies_on_Learning_(2012).pdf (Accessed 23 November 2018).

Hughes, J. E. 2005. The role of teacher knowledge and learning experiences in forming technologyintegrated pedagogy. Journal of Technology and Teacher Education 13(2): 277-302.

Jaffer, S., D. Ng'ambi and L. Czerniewicz. 2007. The role of ICTs in higher education in South Africa: One strategy for addressing teaching and learning challenges. International Journal of Education and Development using Information Technology (IJEDICT) 3(4): 131-142.

Jude, L. T., M. A. Kajura and M. P. Birevu. 2014. Adoption of the SAMR model to access ICT pedagogical adoption: A case of Makerere University. International Journal of e-Education, eBusiness, e-Management and e-Learning 4(2): 106-115.

Kafai, Y. 2001. The educational potential of electronic games: From games-to-teach to games-to-learn. http://culturalpolicy.uchicago.edu/conf2001/papers/kafai.html (Accessed 5 August 2018).

Kapp, K. M. 2012. The gamification of learning and instruction: Games-based methods and strategies for training and education. San Francisco, CA: Pfeiffer.

Kebritchi, M., A. Hirumi and H. Bai. 2010. The effects of modern mathematics computer games on mathematics achievement and class motivation. Computers \& Education 55(2): 427-443.

Kirriemuir, J. and A. McFarlane. 2004. Literature review in games and learning. Futurelab Series, Report 8: 1-35.

Lerman, S. and R. Zevenberger. 2006. Maths, ICT and pedagogy: An examination of equitable practice across diverse settings. In Proceedings of the $30^{\text {th }}$ Conference of the International Group for the Psychology of Mathematics Education, ed. J. Novatna, H. Moraova, M. Kratka, and N. Stehlikova. 16-21 July 2006. Prague: PME.

Lin, M. H., H. C. Chen and K. S. Liu. 2017. A study of the effects of digital learning on learning motivation and learning outcome. Journal of Mathematics Science and Technology Education (EURASIA) 13(7): 3553-3564.

Liu, M., L. Horton, J. Olmanson and P. Toprac. 2011. A study of learning and motivation in a new media enriched environment for middle school science. Educational Technology Research and Development 59(2): 249-265.

Malone, T. 1980. What makes things fun to learn? Heuristics for designing instructional computer games. In Proceedings of the $3^{\text {rd }}$ ACM SIGSMALL Symposium and the $1^{\text {st }}$ SIGPC Symposium. Palo Alto: USA.

Martens, R., J. Gulikers and T. Bastiaens. 2004. The impact of intrinsic motivation on e-learning in authentic computer tasks. Journal of Computer Assisted Learning 20(5): 368-376.

Marzano, R. J., B. B. Gaddy and C. Dean. 2000. What works in classroom instruction. Aurora, CO: Midcontinent Research for Education and Learning.

McFarlane, A., A. Sparrowhawk and Y. Heald. 2002. Report on the educational use of games. TEEM (Teachers evaluating educational multimedia), Cambridge.

McMillan, J. H. and S. Schumacher. 2006. Research in education: Evidence-based inquiry. $6^{\text {th }}$ Edition. 
Boston: Pearson.

Mouyabi, J. S. M. 2011. Higher education in the wake of new ICT: Reaping the benefits of creating more problems through e-learning? South African Journal of Higher Education 25(6): 1178-1189.

Pelgrum, W. J. 2001. Obstacles to the integration of ICT in education: Results from a worldwide educational assessment. Computers \& Education 37(2): 163-178.

Plomp, T. and W. J. Pelgrum. 1993. Restructuring of schools as a consequence of computer use? International Journal of Educational Research 19(2):185-195.

Prensky, M. 2001. Digital game-based learning. New York: McGraw-Hill.

Prensky, M. 2003. Digital game-based learning. ACM Computers in Entertainment 1(1): 1-4.

Randall, J. M., B. A. Morris, C. D. Wetzel and B. V. Whitehill. 1992. The effectiveness of games for educational purposes: A review of recent research. Simulation and Gaming 23: 261-276.

Ryan, R. M. and E. L. Desi. 2000. Intrinsic and extrinsic motivations: Classic definitions and new directions. Contemporary Educational Psychology 25: 54-67.

Sakai, K. and S. Shiota. 2016. A practical study of mathematics education using gamification. International Association for Development of the Information Society. Melbourne, Australia, Dec 6-8, 2016.

Saljo, R. 2010. Digital tools and challenges to institutional traditions of learning: Technologies, social memory and the performative nature of learning. Journal of Computer Assisted Learning 26: 5364.

Schute, V. J. and M. Ventura. 2013. Stealth assessment: Measuring and supporting learning in games. Cambridge, MA: Massachusetts Institute of Technology Press Books.

Smith, J. B., V. E. Lee and F. M. Newmann. 2001. Improving Chicago's schools: Instruction and achievement in Chicago elementary schools. University of Chicago, Consortium on Chicago School Research.

Spencer, P. 2013. iPads: Improving Numeracy learning in the early years. In Mathematics Education: Yesterday, today and tomorrow. Proceedings of the $36^{\text {th }}$ annual conference of the Mathematics Education Research Group of Australasia, ed. V. Steinle, L. Ball and C. Bardini. Melbourne, VIC: MERGA.

Tshibalo, A. E. 2007. The potential impact of computer-aided assessment technology in higher education. South African Journal of Higher Education 21(1): 684-693.

Vander Ark, T. 2011. Getting smart: How digital learning is changing the world. New York: JosseyBass.

Vanderlinde, R. and J. Van Braak. 2011. A new ICT curriculum for primary education in Flanders: Defining and predicting teachers' perceptions of innovations attributes. Journal of Educational Technology \& Society 14(2): 124-135.

Villagrasa, S., D. Fonseca, E. Redondo and J. Duran. 2014. Teaching case of gamification and visual technologies for education. Journal of Cases on Information Technology (JCIT) 16(4): 38-57.

Vos, N., H. Van der Meijden and E. Denessen. 2011. Effects of constructing versus playing an educational game on student motivation and deep learning strategy use. Computers \& Education 56(1): 127-137.

Waghid, Z. and F. Waghid. 2016. Examining digital technology for (higher) education through action research and critical discourse analysis. South African Journal of Higher Education 30(1): 265284.

Wankle, C. 2011. Teaching arts and science with new social media (Vol. 3). New York: Emerald Group Publishing Limited.

Warschauer, M. 2007. A teacher's place in the digital divide. In Information and communication technologies: Considerations of current practices for teachers and teacher educators: $106^{\text {th }}$ Yearbook of the National Society for the Study of Education, ed. L. Smolin, K. Lawless and N. C. Burbules. Malden, MA: Blackwell. 
Werbach, K. and D. Hunter. 2012. For the win: How game thinking can revolutionize your business. Wharton Digital Press.

Wideman, H. H., R. D. Owston, C. Brown, A. Kushniruk, F. Ho and K. C. Pitts. 2007. Unpacking the potential of educational gaming: A new tool for gaming research. Simulation \& Gaming 38(1): $10-30$

Windschitl, M. 1998. The WWW and classroom research: What path should we take? Educational Researcher 27(1): 28-33. 